\title{
TONGKAT ISTIWA', GLOBAL POSITIONING SYSTEM (GPS) DAN GOOGLE EARTH UNTUK MENENTUKAN TITIK KOORDINAT BUMI DAN APLIKASINYA DALAM PENENTUAN ARAH KIBLAT
}

\author{
Anisah Budiwati \\ Universitas Islam Indonesia (UII), Yogyakarta \\ e-mail: anisahbudiwati@gmail.com
}

\begin{abstract}
There are at least three ways to determine the position or the coordinates of a spot on the Earth's surface. They are: istiwa' sticks, Global Positioning System (GPS), and Google Earth. Istiwa' stick is used without technology operations, while GPS and Google Earth are used with technology. Until now, the use of GPS and Google Earth is still a passively consumptive, without their critical analytical effort. This qualitative research using descriptive analytic mathematical methods. The objective of this study is the to know the theory, applications, and accuracy of the istiwa' stick, GPS, and Google Earth comparatively. The study found that the istiwa' stick is one of the alternatives way to determine the coordinates of the Earth which uses the theory of spherical trigonometry calculations simply without assistance. Whereas GPS and Google Earth use principles of geodetic scientifically. In terms of applications, the most practical and accurate is GPS, and then followed by Google Earth, and the last is istiwa'stick.
\end{abstract}

[]

Setidaknya ada tiga cara untuk menentukan posisi atau titik koordinat suatu tempat di permukaan Bumi, yaitu tongkat istiwa', Global Positioning System (GPS), dan Google Earth. Tongkat istiwa' digunakan tanpa bantuan teknologi, sedangkan GPS dan Google Earth digunakan dengan teknologi. Sampai saat ini, penggunaan GPS maupun Google Earth masih bersifat konsumtif pasif, tanpa adanya upaya analitis kritis. Penelitian kualitatif ini menggunakan metode deskriptif analitik matematis. Penelitian ini memiliki tujuan untuk mengetahui teori, aplikasi, maupun akurasi tongkat istiwa', GPS, dan Google Earth secara komparatif. Penelitian ini menemukan bahwa tongkat istiwa' adalah salah satu alternatif penentuan titik koordinat Bumi yang menggunakan teori perhitungan spherical trigonometry secara sederhana tanpa bantuan, sedangkan GPS dan Google Earth menggunakan prinsip keilmuan geodesi yang lebih teliti. Dari segi aplikasi, yang paling praktis dan akurat adalah GPS. Kemudian disusul Google Earth, dan tongkat istiwa'.

Keywords: titik koordinat bumi; tongkat Istiwa; GPS; Google Earth 


\section{Pendahuluan}

Sampai saat ini, penentuan posisi atau titik koordinat suatu tempat di permukaan Bumi dengan bantuan teknologi yakni GPS ataupun Google Earth (GE) dirasa masih bersifat konsumtif pasif. Jika melihat penggunaan teknologi GPS dan GE baik oleh para praktisi ilmu falak maupun masyarakat lainnya hanya sebatas konsumtif tanpa adanya upaya analitis kritis. Kesulitan timbul manakala sistem satelit yang tersedia pada GPS ataupun data yang ditampilkan pada GE dalam kondisi error mistakes. Terbatasnya akses GPS maupun GE pun sangat terasa bagi masyarakat yang berada di daerah yang belum terjamah teknologi.

Kemungkinan yang bisa dilakukan masyarakat yang kesulitan akses tersebut adalah menggunakan metode penentuan titik koordinat yang lebih praktis yakni tongkat istiwa'. Pembahasan tongkat istiwa' sampai saat ini masih dibahas dalam tataran teknis, padahal alat ini merupakan alat ukur yang pada zamannya sangat akurat. Dengan menggunakan konsep tongkat istiwa' seseorang dapat memperoleh informasi titik koordinat Bumi tanpa teknologi. Tentunya, kajian lebih dalam akan sangat diperlukan ketika teori yang diterapkan pada tongkat istiwa' telah diketahui. Hal ini akan sangat memungkinkan memberikan koreksi agar hasil lintang bujur yang diperoleh dari tongkat istiwa' dapat akurat atau hampir menyamai hasil yang disajikan GPS atau GE, alat yang selama ini ada.

Penggunaan tongkat istiwa' dalam penentuan titik koordinat Bumi pada dasarnya sangat terkait dengan sebuah ayat al-Qur'an surat al-Furqan: 45 yang membahas bayang-bayang Matahari. Dari ayat ini, Allah memberikan petunjuk kepada manusia untuk merenungi dan mempelajari keterkaitan posisi Matahari dengan planet yang kita tempati yaitu Bumi, di mana dengan adanya revolusi Matahari dan rotasi Bumi, bayangan benda apapun di permukaan Bumi dapat memanjang dan memendek dalam setiap harinya. Tongkat istiwa' yang digunakan untuk mengetahui pergerakan matahari ini menjadi hal yang perlu dikaji dalam ilmu pengetahuan. Teori apakah yang digunakan tongkat istiwa' dalam menentukan titik koordinat Bumi?

Dalam penentuan titik koordinat Bumi, metode ini tidak banyak diulas lebih mendalam sampai pada segi teori, aplikasi, dan akurasinya. Belum ada 
sebuah kajian yang berorientasi kepada aspek-aspek yang dapat memunculkan kembali telaah metode tongkat istiwa' sebagai alat praktis untuk menentukan titik koordinat Bumi. Tongkat istiwa' merupakan alat sesederhana yang dapat digunakan oleh umat Islam, khususnya bagi masyarakat yang tidak dapat menjangkau GPS dan mengakses GE.

Seiring berkembangnya ilmu pengetahuan dan teknologi, keilmuan lain seperti geodesi menawarkan pengukuran titik koordinat permukaan Bumi yang lebih akurat yaitu menggunakan prediksi bentuk Bumi yang tidak bulat yakni ellipsoid. ${ }^{1}$ Metode tongkat istiwa' perlu dibandingkan dengan beberapa metode, termasuk beberapa yang memakai keilmuan geodesi sebagai dasar, seperti GPS (Global Positioning System) dan GE. GPS dalam berbagai inovasi juga telah dimodifikasi dalam bentuk peralatan elektronik seperti dipasang pada handphone atau kendaraan. Data GPS yang diperoleh ini merupakan hasil penerimaan reciever atau GPS dari pencitraan satelit udara. Sistem GPS yang mempertimbangkan parameter bentuk Bumi secara geodetik untuk menentukan titik koordinat Bumi ini perlu dibahas sebagai pembanding untuk menguji keakuratan tongkat istiwa'.

Dengan demikian hal ini menjadi pertimbangan penulis untuk dapat menganalisis fungsi tongkat istiwa' dalam menentukan titik koordinat Bumi dan aplikasinya dalam penentuan arah kiblat. Kajian ilmiah tentang hal ini juga dirasa sangat perlu terutama terkait dengan bagaimana teori, metode, dan aplikasi tongkat istiwa' apabila dibandingkan dengan GPS dan GE.

\section{Spherical Trigonometry dan Geodesi untuk Menentukan Titik Koordinat Bumi}

Dua teori akan digunakan untuk menganalisis tema penelitian ini, yaitu: Pertama, teori trigonometri bola atau yang disebut dengan spherical trigonometry. Teori ini merupakan studi yang berkonsentrasi pada geometri permukaan sebuah bola. ${ }^{2}$ Teori ini digunakan dalam menentukan arah pada satu titik posisi di permukaan bola. Teori ini dapat diterapkan pula pada

${ }^{1}$ Joenil Kahar, Geodesi (Bandung: ITB, 2008), h. 5.

2W. M, Smart, Textbookon Spherical Astronomy (New York: Cambridge University Press, 1977), h. 1.

AL-AHKAM

p-ISSN: 0854-4603; e-ISSN: 2502-3209 
penentuan titik koordinat pada bola Bumi dan bola langit. Kedua, teori Geodesi, yaitu ilmu tentang pengukuran dan pemetaan permukaan Bumi. ${ }^{3}$ Geodesi merupakan cabang ilmu matematika terapan, yaitu berupa pengukuran di permukaan Bumi. Ilmu ini digunakan untuk menentukan: 1) bentuk dan ukuran Bumi, 2) posisi atau koordinat suatu titik, 3) panjang dan arah garis, dan 4) mempelajari medan gravitasi Bumi. ${ }^{4}$

Teori trigonometri bola dan teori geodesi dalam hal persamaannya dapat menyelesaikan penentuan titik koordinat, azimut, arah, maupun jarak satu tempat ke tempat lainnya. Namun hal yang membedakan, adalah pendekatan bentuk Buminya. Teori trigonometri bola menggunakan konsep Bumi berbentuk bola dan teori Geodesi menggunakan bentuk pendekatan ellipsoid. Pendekatan ini akan menghasilkan konsep, teori, dan akurasi yang berbeda. Dengan demikian, dua teori ini digunakan untuk menganalisis teori apa yang mendasari cara kerja tongkat istiwa', GPS dan GE.

Penelitian ini termasuk dalam jenis penelitian kualitatif yang bersifat deskriptif (descriptive research) yang bertujuan untuk mengetahui lebih detail tentang kajian tongkat istiwa' dan perbandingannya dengan GPS dan GE dari segi teori, metode dan akurasinya dalam menentukan titik koordinat Bumi dan arah kiblat. Sumber data dalam penelitian ini ada dua, sumber primer diperoleh dari hasil observasi (data pengamatan). Sedangkan sumber data sekunder berasal dari hasil dokumentasi, yaitu literatur yang membahas metode penentuan titik koordinat Bumi yang terkait dengan metode praktis tongkat istiwa' dan perbandingannya dengan GPS dan GE dalam menentukan lintang dan bujur di permukaan Bumi.

Teknik pengumpulan data menggunakan teknik observasi dan dokumentasi. Observasi (pengamatan) digunakan untuk mengambil data sistem kerja tongkat istiwa' dengan menggunakan beberapa peralatan seperti papan, tongkat, penggaris, data ephemeris, GE, GPS, dan tabel pengamatan yang telah

${ }^{3}$ Friedrich Robert Helmert, Die mathematischen und physikalischen Theorien der hoheren Geodäsie (Leipzig: Band 1. G. Teubner, 1880), h. 1.

4W. J. Krakiwsky, dan D. E. Wells, Coordinate Systems in Geodesy, Canada: Departement of Geodesy and Geomatics Engineering University of New Brunswick Frederiction N.B., 1971), h. 4. 
disusun. ${ }^{5}$ Kemudian melakukan observasi pada GPSmap 76 Garmin dan software GE yang dikoneksikan dengan internet. Selain itu menggunakan metode dokumentasi untuk mengumpulkan data terkait tongkat istiwa', GPS dan GE yang terdapat pada literatur terkait.

Analisis data, penulis menggunakan teknik deskriptif analitik matematis, ${ }^{6}$ yakni analisis dengan cara menggambarkan teori perhitungan dan metode tongkat istiwa', GPS dan GE dengan perhitungan. ${ }^{7}$ Kemudian menelusuri seberapa tinggi tingkat akurasi tongkat istiwa' dibandingkan dengan GPS dan GE dengan analisis komparatif. Analisis dilakukan dengan menggunakan teknik perhitungan untuk mendapatkan kesimpulan teori, metode, dan perbandingan ketiga metode dalam memperoleh data titik koordinat Bumi.

\section{Metode Penentuan Titik Koordinat Bumi Menggunakan Tongkat Istiwa'}

\section{Definisi Tongkat Istiwa'}

Tongkat istiwa' terdiri dari dua kata, tongkat dan istiwa'. Tongkat adalah sepotong bambu (rotan, kayu, dsb) yang agak panjang (untuk menopang atau pegangan ketika berjalan, menyokong). ${ }^{8}$ Sedangkan istiwa' dalam kamus alBisri bermakna keadaan lurus. ${ }^{9}$ Jadi tongkat istiwa' merupakan tongkat yang

5Teknik pengumpulan data dengan observasi digunakan bila penelitian berkenaan dengan perilaku manusia, proses kerja, gejala alam dan bila responden yang diamati tidak terlalu besar. Dalam hal ini penelitian penulis terkait dengan proses kerja dan gejala alam yang dalam teknik untuk mengumpulkan data yakni dengan observasi. Baca: Basrowi, dan Suwandi, Memahami Penelitian Kualitatif(Jakarta: Rineka Cipta, 2008), h. 94.

${ }^{6}$ Analisis matematis ditekankan pada fokus pembahasan penelitian ini yakni dalam mengurai teori, metode, dan penerapan aplikasi dalam memahami teori, metode dan akurasi ketiga metode penentuan titik koordinat Bumi yaitu tongkat istiwa', GPS dan google earth. Analisis yang digunakan adalah matematis karena logika matematis berkembang seiring dengan kajian matematika dan pembahasan penelitian ini dalam rangka menemukan kerangka teori ketiga metode itu dalam keilmuan astronomi, navigasi, dan geodesi.

7Sebagaimana dijelaskan Basrowi (2008), bahwa dalam masalah penelitian kualitatif, masalah yang dibawa peneliti masih bersifat sementara, sehingga dalam kaitannya dengan teori penelitian kualitatif bersifat membangun teori, dan bukan menguji hipotesis atau teori. Begitu pula dalam penelitian ini yang pada perkembangannya membangun teori praktis tongkat istiwa' untuk menentukan titik koordinat Bumi. Basrowi, dan Suwandi, Memahami Penelitian Kualitatif, h. 39.

8Heppy El Rais, Kamus Ilmiah Populer (Yogyakarta: Pustaka Pelajar, 2012), h. 684. 354.

9Warson Munawir, al-Munawir Kamus Arab-Indonesia (Surabaya: Pustaka Progressif, 1997), h. 
dikondisikan dalam posisi berdiri dalam keadaan yang lurus. Hal ini diperkuat dengan adanya istilah istiwa' yang digunakan para ahli falak sebagai tongkat yang digunakan untuk mengetahui ketinggian Matahari, khususnya pada penentuan bayangan tongkat ketika kulminasi (dalam menentukan waktu Dzuhur).

Sejatinya, tongkat istiwa' adalah istilah yang dipakai kalangan pesantren untuk menyebut tongkat yang digunakan untuk mengukur tinggi Matahari. Tongkat istiwa' terdiri dari dua bagian yaitu tiang (gnomon) dan bidang atau piringan horizontal untuk menangkap bayangan dalam memberikan informasi waktu dan posisi bayangan. Tongkat istiwa' bekerja secara otomatis membentuk bayangan tergantung posisi Matahari. Ketika Matahari terbit dan sinarnya mengenai tongkat yang lurus, sehingga akan terbentuk panjang bayangan yang bisa sampai melebihi panjang tongkat bergantung pada posisi Matahari di langit.

\section{Sejarah Tongkat Istiwa'}

Salah satu kegunaan tongkat istiwa' adalah dimanfaatkan untuk penentuan lintang dan bujur ini bermula dari bentuk sundial atau jam Matahari terlebih dahulu, ${ }^{10}$ meskipun secara fisik fungsi kedua alat ini memiliki perbedaan yang tidak begitu jauh. Menurut catatan sejarah, sundial atau jam Matahari merupakan jam tertua dalam peradaban manusia. Jam ini telah dikenal sejak tahun 3500 SM di Mesir. Pembuatan jam Matahari di dunia Islam dilakukan oleh Ibnu al-Shatir, seorang ahli Astronomi Muslim (1304-1375 M). "Ibnu alShatir merakit jam Matahari yang bagus sekali untuk menara Masjid Umayyah di Damaskus" sebagaimana disebutkan David A. King dalam karyanya bertajuk The Astronomy of the Mamluks. Berkat penemuannya itu, ia kemudian dikenal sebagai muwaqqit (pengatur waktu ibadah) pada Masjid Umayyah di Damaskus, Suriah. Jam yang dibuat Ibnu al-Shatir itu masih tergolong jam

10Dalam karya Ehsan Masood, Ilmuwan-ilmuan Muslim Pelopor Hebat di Bidang Sains Modern (2009:64) disebutkan bahwa Ibnu al-Shatir adalah astronom pertama yang membuat jam Matahari. Dalam bukunya terdapat gambar jam Matahari yang terdapat di salah satu bangunan hebat pertama yang didirikan orang Muslim pada abad ke-14 Masehi, Masjid Ummayyah di Damaskus. Ibnu alShatir bekerja di masjid tersebut sebagai penentu waktu shalat. 
Matahari kuno yang didasarkan pada garis jam lurus. Ibnu al-Shatir membagi waktu dalam sehari dengan 12 jam, pada musim dingin waktu pendek, sedangkan pada musim panas waktu lebih panjang. Jam Mataharinya itu merupakan polar-axis sundial paling tua yang masih tetap eksis hingga kini.

Tongkat istiwa' dikenal pula dengan sundial atau orang Jawa menyebutnya bencet, ${ }^{11}$ tongkat istiwa' dapat disebut pula dengan sundial, alat yang terbuat dari sepotong kayu yang tegak lurus (gnomon) pada bidang horizontal. Di mana menurut catatan sejarah, manusia telah menggunakannya di Mesir sekitar 3500 tahun yang lalu, yang dipakai sebagai jam untuk mengawali, mengakhiri, atau mengulangi suatu pekerjaan. ${ }^{12}$

\section{Basis Teori Tongkat Istiwa'}

Tongkat istiwa' dalam penentuan titik koordinat Bumi sejatinya menggunakan sistem kerja dari konsep astronomi, di mana kaidah trigonometri menjadi kaidah perhitungannya dan input data deklinasi yang digunakan adalah bersifat astronomis. Berdasarkan pada pembahasan yang lalu, metode tongkat istiwa ${ }^{\prime}$ diketahui memiliki geometri ${ }^{13}$ penentuan titik koordinat Bumi yang secara matematis hanya menggunakan sinar Matahari dan sebuah tongkat. Hal ini menunjukkan bahwa sistem kerja yang dipakai adalah menggunakan kaidah trigonometri bola.

Jika sinar Matahari yang menyentuh ujung tongkat istiwa' itu diperpanjang sampai ke bola langit, maka terbentuk suatu sudut perpotongan dengan perpanjangan titik zenit. Sudut yang dihasilkan merupakan cotangen sudut dari

\section{h. 27.}

11Muhyiddin Khazin, Ilmu Falak dalam Teori dan Praktik, Cet I (Yogyakarta: Buana Pustaka, 2004),

${ }^{12}$ Menurut Darsa Sukartadireja (Kepala BP Planetarium dan Observatorium Jakarta), yang dinamakan tongkat Matahari yakni sebuah tiang atau tongkat yang ditanam tegal di atas pelataran yang digunakan untuk mengetahui ketinggian Matahari melalui bayang-bayangnya. Lebih dalam dibaca di Darsa Sukaetadireja, Teknik Observasi Posisi Matahari untuk Menentukan Waktu Shalat dan Arah Kiblat. Darsa Sukaetadireja, Teknik Observasi Posisi Matahari untuk Menentukan Waktu Shalat dan Arah Kiblat, Makalah yang disampaikan dalam Workshop Nasional mengkaji Ulang Metode Penetapan Awal Waktu Shalat dan Arah Kiblat dalam perspektif Ilmu Syariah dan Astronomi di UII Yogyakarta, 2009.

${ }^{13}$ Geometri: 1) Cabang matematika uang menerangkan sifat-sifat garis, sudut, bidang, dan ruang; 2) Ilmu ukur, Heppy El Rais, Kamus Ilmiah Populer (Yogyakarta: Pustaka Pelajar, 2012), h. 216. 
panjang tongkat dan panjang bayangan yang dibentuk Matahari saat melewati meridian pengamat. Perhatikan perpanjangan sinar Matahari dan tongkat ke luar permukaan Bumi, di mana sudut EOZ adalah jarak zenit - Matahari. Pada bola langit dengan tata koordinat horizon di atas, lintang tempat $(\phi)$ dapat diketahui dengan cara mengurangkan jarak zenit Matahari dengan deklinasi Matahari $(\delta)$.

Posisi bayangan yang condong ke sebelah selatan menunjukkan bahwa keberadaan pengamat berada pada lintang selatan Bumi. Posisi deklinasi Matahari kala itu membantu untuk mengetahui selisih jarak zenit - Matahari dengan deklinasi sehingga diketahui sudut lintang. Sedangkan bayangan terpendek yang dibentuk menunjukkan waktu pengukuran meridian lokal yang menunjukkan selisih dengan meridian utama yakni (misal di Indonesia terbagi menjadi tiga yaitu WIB (105\%), WITA (120), dan WIT (135'). Sehingga selisih jam pengamatan dengan meridian lokal akan menunjukkan bujur tempat tersebut.

Mengamati cara kerja penggunaan tongkat istiwa', alat ini sangat berkaitan dengan Matahari karena fungsi tongkat istiwa' itu sendiri adalah menangkap bayangan dan memberikan informasi ketinggian Matahari. Sehingga hal yang perlu diingat adalah penggunaan tongkat istiwa' hanya bisa digunakan sepanjang Matahari di atas ufuk (baik pagi, siang maupun sore hari). Membahas teori tongkat istiwa' berdasarkan pengamatan sangat berkaitan dengan data deklinasi Matahari yang termasuk pada data geosentrik atau geodetik.

\section{Aplikasi dalam Penentuan Arah Kiblat}

Pada dasarnya, tongkat istiwa' lebih banyak digunakan untuk menentukan arah mata angin, ketinggian Matahari, dan awal waktu shalat, namun tongkat istiwa' dapat pula digunakan untuk menentukan arah kiblat. Dalam aplikasi penentuan arah kiblat, tongkat istiwa' banyak digunakan sebagai alternatif dalam menentukan kiblat, di antaranya: a) Sebagai penanda bayangan kiblat pada waktu rashd al-qiblat harian maupun global. Hal ini sebagaimana penjelasan pada bab sebelumnya mengenai bayangan rashd al-qiblat yang dapat berubah-ubdah sesuai dengan nilai deklinasinya. b) Sebagai pembantu penentuan arah mata angin dan mendapatkan sudut arah kiblat. Fungsi tongkat istiwa' lebih dominan pada penentuan arah utara sejati, baru kemudian dapat dibuat trigonometri perhitungan untuk arah kiblat. 
Dalam aplikasinya menentukan arah kiblat, tongkat istiwa' berfungsi sebagai sudut pembantu untuk menemukan azimut Matahari dan azimut kiblat. Cara kerja tongkat istiwa' seperti ini hampir sama dengan konsep mizwala yakni dengan mencari azimut Matahari terlebih dahulu untuk kemudian dicari azimut kiblat tempat tersebut.

\section{Metode Penentuan Titik Koordinat Bumi Menggunakan GPS}

\section{Definisi GPS (Global Positioning System)}

GPS (Global Positioning System) adalah sistem radio navigasi dan penentuan posisi menggunakan satelit. ${ }^{14}$ Nama formalnya biasa disebut NAVSTAR GPS, kepanjangannya adalah Navigation Satellite Timing and Ranging Global Positioning System. Dalam penjelasan Global Positioning System pada website garmin.co.id disebutkan bahwa global positioning system (GPS) adalah sistem navigasi berbasis satelit yang terdiri dari jaringan 24 satelit ${ }^{15}$ yang mengorbit oleh Departemen Pertahanan Amerika Serikat. Pada awalnya GPS digunakan untuk aplikasi militer, namun pada 1980-an, Pemerintah membuat sistem yang tersedia untuk penggunaan sipil.GPS bekerja di semua kondisi cuaca, di mana saja di dunia selama 24 jam sehari.

Ekadinata menyatakan bahwa elemen satelit terdiri dari 24 satelit di luar angkasa (21 aktif, 3 cadangan) yang beredar di ketinggian 19,300 km di atas permukaan Bumi. Jaringan satelit ini disebut konstelasi GPS. Ketinggian tersebut dibutuhkan agar satelit dapat mencakup areal yang cukup luas. Posisi satelit tersebut di luar angkasa diatur sedemikian rupa sehingga pengguna di Bumi dapat menangkap paling tidak 4 sinyal satelit setiap waktu. ${ }^{16}$

\footnotetext{
${ }^{14}$ Hasanuddin Abidin, Geodesi Satelit (Jakarta: PT. Pradnya Paramita), h. 171.

${ }^{15}$ Sebuah penerima GPS harus mengunci sinyal satelit setidaknya tiga satelit untuk menghitung posisi 2D (garis lintang dan bujur) dan penelusuran pergerakan GPS unit (Tracking). Dengan empat atau lebih satelit di tampilan, receiver dapat menentukan posisi 3D ke pengguna (lintang, bujur dan ketinggian). Setelah pengguna posisi telah ditentukan, unit GPS dapat menghitung informasi lain, seperti kecepatan, arah, track atau jalur perjalanan, jarak perjalanan, jarak ke tujuan, waktu Matahari terbit dan Matahari terbenam dan banyak lagi (http://garmin.co.id/search/membaca-lintang-danbujur-di-gps)

16 Andree Ekadinata , dkk., Sistem Informasi Geografis untuk Pengelolaan Bentang Lahan Berbasis Sumber Daya Alam (Bogor: World Agoforestry Centre, 2008), h. 12.
} 
Gambaran sistem kerja atau cara kerja Satelit GPS yaitu melingkari Bumi dua kali sehari dalam orbit yang sangat tepat dan mengirimkan sinyal informasi ke Bumi. Orbit satelit berinklinasi 55 derajat terhadap bidang ekuator dengan ketinggian rata-rata dari permukaan Bumi sekitar $20.200 \mathrm{~km}$. Satelit GPS bergerak dalam orbitnya dengan kecepatan kira-kira 3,87 km/ detik dan mempunyai periode 11 jam 58 menit (sekitar 12 jam). Sehingga 4 sampai 10 satelit GPS akan selalu dapat diamati pada setiap waktu dari manapun di permukaan Bumi. ${ }^{17}$ Penerima GPS menerima informasi ini dan triangulasi yang digunakan untuk menghitung lokasi pasti pengguna.

\section{Sejarah GPS (Global Positioning System)}

Sejarah GPS diawali dari perkembangan bidang Geodesi satelit yang dapat dikatakan mulai semarak dengan diluncurkannya satelit-satelit buatan manusia. Sebagaimana diterangkan Abidin (2001), sejarah ruang lingkup geodesi satelit dimulai sejak peluncuran satelit buatan manusia yang pertama ke luar angkasa, yaitu satelit Sputnik-1 pada 4 Oktober 1957 oleh Uni Soviet dan bertahan hidup sampai awal 1958. Sejak saat itu Geodesi satelit berkembang menjadi suatu subdisiplin ilmu Geodesi yang mandiri dan kuat. Kemudian Sputnik-2 diluncurkan pada tanggal 3 November 1957 dan membawa makhluk hidup pertama ke luar angkasa yaitu seekor anjing bernama Laika. Setelah itu pada tanggal 31 Januari 1958, Amerika Serikat meluncurkan satelitnya yang pertama yaitu Explorer 1 yang menemukan sabuk radiasi Van Allen di sekitar Bumi. ${ }^{18}$

Satelit GPS yang pertama diluncurkan pada bulan Februari 1978 dengan berat satelit sekitar 2000 ponds dan bentangan panel surya untuk tenaga baterainya sepanjang 17 feet. Adapun power transmitternya hanya 500 watt. Semua satelit GPS tersebut dikendalikan dari Bumi dengan pusat kontrol di Schriever Air Force Base (dahulu Falcon AFB) Colorado dan beberapa tempat untuk stasiun monitor yang tersebar di seluruh muka Bumi.

Sistem GPS disetujui oleh Departemen Pertahanan Amerika Serikat pada tahun 1978, dan secara resmi sistem GPS dinyatakan operasional pada tahun

17Hasanuddin Abidin, Geodesi Satelit (Jakarta: PT. Pradnya Paramita, 2001), h. 180.

18Ibid, h. 3.

74 || Volume 26, Nomor 1, April 2016

AL-AHKAM p-ISSN: 0854-4603; e-ISSN: 2502-3209 
1994. Biaya pembangunan sistem GPS yang pernah dilaporkan adalah sekitar 10 milyar US dollar, sementara biaya operasi dan pemeliharaannya per tahun berkisar dari 250 sampai 500 juta USD. Sejarah pembangunan serta karakteristik sistem GPS secara komprehensif dapat dibaca dalam buku karya Parkinson, et.al (1996).

Sampai saat ini sudah ada empat sistem satelit navigasi yang pernah dikembangkan dan dimanfaatkan, yaitu sistem Transit (Doppler) dan GPS milik Amerika Serikat, dan Tsikada dan GLONASS (Global Navigation System) miliki Rusia. ${ }^{19}$ Sistem Transit didesain pada tahun 1958 dan dinyatakan operasional pada tahun 1964 (untuk pihak militer) dan 1967 (untuk pihak sipil). Sistem Tsikada adalah sistem Rusia yang mirip dengan Transit yang juga operasional sekitar pertengahan 1960-an. Pada saat ini kedua sistem satelit ini praktis sudah tidak banyak digunakan lagi, tergantikan oleh sistem-sistem GPS dan GLONASS. Dari kedua sistem yang operasional tersebut, GPS adalah sistem yang paling populer dan paling banyak digunakan saat ini.

\section{Basis Teori GPS (Global Positioning System)}

Pemanfaatan GPS dalam menentukan arah kiblat khususnya dalam penyajian data titik koordinat Bumi tidak lain merupakan pemanfaatan keilmuan Geodesi. GPS termasuk pada sub bidang geodesi satelit, selain dari sub-sub bidang lain yakni Geodesi geometrik, Geodesi fisik, Geodesi matematik, dan Geodesi dinamik. Geodesi satelit termasuk pada perkembangan ilmu pengetahuan dan teknologi serta bidang-bidang aplikasi baru yang dikenal selain dari geodesi kelautan dan geodesi geofisik. Geodesi satelit telah berkembang menjadi suatu sub-disiplin ilmu geodesi yang mandiri dan kuat, sejak peluncuran satelit buatan manusia yang pertama ke luar angkasa, yaitu satelit SPUTNIK-1 pada 4 Oktober 1957.

Berdasarkan pendekatan dalam penggunaan satelit, penentuan posisi dengan menggunakan GPS, tidak lain termasuk pada geodesi satelit geometrik, ${ }^{20}$

\footnotetext{
${ }^{19}$ Ibid, h. 171.

20Pendekatan dalam menggunakan satelit dikategorisasikan menjadi dua yaitu geodesi satelit geometrik dan geodesi satelit dinamik. Jika geodesi satelit geometrik, satelit dianggap sebagai target, titik kontrol, atau wahana pengukur, maka dalam geodesi satelit dinamik, satelit dianggap sensor
} 
di mana geodesi satelit geometrik ini banyak berperan dalam penentuan posisi serta variasi spasial dan temporalnya sehingga satelit berfungsi sebagai satelit dianggap sebagai target, titik kontrol, atau wahana pengukur.

Kemudian melihat sistem pengamatan geodesi satelit, GPS termasuk pada sistem pengamatan Bumi ke angkasa atau disebut pula dengan satelit navigasi seperti sistem lainnya yaitu sistem fotografi satelit (satelite photography), SLR (Satelite Laser Ranging), LLR (Lunar Laser Ranging), VLBI (Very Long Baseline Interferometry), satelit Altimetri seperti TOPEX Poseidon, dan satelit navigasi seperti Transit (Doppler), GPS, dan GLONASS. ${ }^{21}$

Dalam konteks sistem satelit navigasi, sistem GPS dan GLONASS menjadi pengganti sistem yang pertama kali ada yaitu sistem TRANSIT (Doppler). Sistem ini adalah sistem satelit navigasi yang pertama kali dibangun. Sistem ini didesain pada tahun 1985 dan dinyatakan operasional pada tahun 1964 untuk pihak militer dan 1967 untuk pihak sipil. Saat ini sistem satelit ini praktis sudah tidak digunakan lagi, digantikan oleh sistem-sistem GPS dan GLONASS. Kalau diiringkan maka sistem-sistem yang masih banyak dimanfaatkan dalam bidang geodesi satelit saat ini adalah sistem-sistem SLR, LLR, VLBI, satelit altimetri dan satelit navigasi GPS dan GLONASS. Berkaitan dengan penentuan posisi, sistem yang paling populer dan paling banyak diaplikasikan adalah GPS. Sistem fotografi satelit pada saat ini sudah tidak digunakan lagi, dan juga sistem satelit Doppler dan astronomi geodesi sudah mulai jarang digunakan orang untuk keperluan penentuan posisi. Sedangkan sistem-sistem SLR, LLR, dan VLBI umumnya digunakan untuk melayani aplikasi-aplikasi ilmiah yang menuntut ketelitian posisi yang sangat tinggi. ${ }^{22}$

\section{Aplikasi dalam Penentuan Arah Kiblat}

GPS pada dasarnya memiliki fungsi utama sebagai alat yang dapat menunjukkan posisi titik koordinat suatu tempat dan waktu. Aplikasi GPS dalam

atau prober dari medan gaya berat karena geodesi satelit dinamik berperan dalam penentuan medan gaya berat serta variasi spasial dan temporalnya, Hasanuddin Abidin, Geodesi Satelit, h. 3.

${ }^{21}$ Ibid., h. 8.

22Abidin, Hasanuddin, Geodesi Satelit, h. 8-9.

76 || Volume 26, Nomor 1, April 2016 
penentuan arah kiblat diaplikasikan sebagai alat bantu untuk mendapatkan titik koordinat tempat di permukaan Bumi. Hal ini sebagaimana fungsi utamanya yang dimilikinya yakni menentukan lintang dan bujur tempat dan memberikan informasi waktu. Sebagian besar pemanfaatan GPS yang digunakan dalam penentuan arah kiblat adalah GPS tipe handheld. GPS tipe handheld ini adalah tipe GPS navigasi yang bisa dibawa kemana-mana, tidak seperti GPS lainnya yang berfungsi untuk pemetaan dan geodetik.

Aplikasi GPS ini digunakan untuk mencari titik lokasi tertentu yang diinginkan untuk dilakukan pengukuran arah kiblat. Aplikasi GPS pada penentuan arah kiblat lebih sedikit dibandingkan dengan fungsi tongkat istiwa' dan GE. Aplikasi alat ini adalah ketika diketahui data titik koordinat tempat, maka dapat dilakukan perhitungan kiblat. Perhitungan arah kiblat bisa dilakukan dengan perhitungan segitiga bola atau pun segitiga napier dengan bantuan data GPS. Selanjutnya data tersebut dihitung dan dihasilkan sudut kiblat yang kemudian diukur dengan berbagai metode baik itu theodolit, busur derajat, maupun segitiga kiblat.

\section{Metode Penentuan Titik Koordinat Bumi menggunakan Google Earth}

\section{Definisi Google Earth}

Google Earth (GE) adalah program dunia virtual yang bisa menampilkan semua gambar di dunia yang didapat dari satelit, fotografi udara dan aplikasi Geographic Information System (GIS). ${ }^{23}$ Aplikasi ini berbeda dengan peta biasa yang ditampilkan dalam bentuk 2D, GE menampilkan keseluruhan gambar dalam kerangka bola dunia. GE adalah free program yang dapat didownload di http://earth.google.com.

GE dapat mengakses kota-kota besar secara detail. Gambar-gambar yang dihasilkannya pun memiliki resolusi tinggi sehingga gambar gedung-gedung, orang, bahkan mobil dapat dilihat di kota-kota dan negara bagian tertentu,

\footnotetext{
${ }^{23}$ Efistek.com, Menjelajah Dunia dengan Google Earth dan Maps (Bandung: CV. Yrama widya, 2006), h. 25.
} 
seperti London, Washington DC, dan Seattle. Perbedaannya dengan Google Maps menurut jenisnya, aplikasi GE merupakan salah satu model aplikasi Google GIS yang dapat disebut juga versi desktop. Sedangkan Google Maps adalah salah satu bagian lainnya lagi yang merupakan versi online.

Dijelaskan Efisitek.com bahwa tingkat resolusi yang disediakan dalam GE ditentukan oleh tingkat kemenarikan kota tersebut. Kota-kota yang memiliki tingkat resolusi tinggi antara lain Las Vegas, Cambrige, Fulton Country, dan New York. GE mempermudah pencarian lokasi berdasarkan alamatnya. Namun layanan ini hanya berlaku di negara-negara tertentu saja seperti Amerika Serikat, Canada, dan sebagian negara-negara Eropa. GE juga memungkinkan pencarian titik koordinat. Dalam pencarian manual, user dapat menggerakkan mouse menuju ke tempat-tempat yang diinginkan. ${ }^{24}$

GE memiliki model digital terrain yang dikumpulkan oleh Shuttle Radar Topography Mision (SRTM) milik NASA. Model digital terrain ini memungkinkan objek-objek tertentu dilihat secara tiga dimensi dalam arti ketinggian dari objek-objek tersebut akan terlihat dengan jelas. Sebagai fitur tambahan, Google juga menyediakan fasilitas layer yang memungkinkan user melihat gedunggedung tinggi dalam tiga dimensi. Hal ini sudah bisa dilihat di beberapa kota besar di Amerika Serikat. 25

\section{Sejarah Google Earth}

GE merupakan aplikasi gratis dunia virtual yang bisa didownload secara bebas. ${ }^{26} \mathrm{GE}$ memetakan daerah-daerah di dunia dengan cara menggabungkan gambar-gambar yang diperoleh dari satelit, foto udara, dan GIS. GE ditampilkan dalam bentuk bola dunia tiga dimensi. Sebelum dikenal dengan nama GE aplikasi ini bernama earth viewer. Pada awal pendiriannya, GE sebenarnya tidak dikembangkan oleh Google Inc., tetapi merupakan teknologi yang dikembangkan oleh perusahaan yang bernama Keyhole Inc. Produk ini kemudian dibeli oleh Google Inc. dan pada tahun 2005 diberi nama GE. Saat ini

${ }^{24}$ Ibid, h. 38-39.

25Ibid, h. 39.

26Ibid, h. 13. 
GE dapat digunakan untuk para pengguna PC yang menggunakan sistem operasi Microsoft Windows 2000/XP, MacOS X 10.3.9 ke atas, FreeBSD, dan Linux.

Mengenal lebih dalam, kata Google berasal dari kata "Googol" yang merupakan istilah matematika untuk mengucapkan angka 10100.27 Pada awalnya Google adalah nama sebuah proyek riset yang dilakukan oleh dua pendirinya yakni Larry Page dan Sergey Brin. Proyek tersebut dilakukan ketika mengambil gelar Ph.D di Universitas Stanford, California. Saat kedua pendiri itu membuat hipotesis tentang search engine, mereka menganalisis bahwa adanya keterkaitan antara situs-situs web akan menghasilkan performa pencarian yang lebih unggul apabila dibandingkan search engine yang menggunakan teknik konvensional pada saat itu. Teknis search engine yang ada saat itu hanya merangking urutan berdasarkan berapa banyak kata-kata kunci pencarian yang ditemukan di halaman tersebut.

Efisitek juga menjelaskan bahwa Google pada awalnya diberi nama "BackRub" dikarenakan mereka membuat sistem yang melakukan pengecekan pada backlins untuk mengestimasi tingkat kepentingan sebuah situs. Awalnya prototipe dari search engine Google diletakan di website Universitas Stanford, dengan nama domain Google.stanford.edu. Setelah berkembang, domain Google.com baru didaftarkan pada tanggal 14 September 1997.28

Ketika Google Inc. didirikan pada tahun 1998 di Menlo Park California, investasi awal yang ditanamkan adalah 1,1 juta dolar Amerika, termasuk di dalamnya sebuah cek dari Andy Bechtolsheim-salah seorang pendiri Sun Microsystem- senilai 100 ribu dolar Amerika. Pada bulan Maret tahun 1999, perusahaan ini memindahkan kantornya ke sebuah kompleks perkantoran di 165 University Avenue di Palo Alto. Kompleks ini juga merupakan markas dari beberapa perusahaan start-up Silicon Valley lainnya. Adapun gedung Amphitheatre Parkway yang merupakan tempat yang digunakan oleh Google Inc saat ini, mulai ditempati pada tahun 2003. Kompleks ini sekarang terkenal dengan nama Googleplex atau sering juga disebut sebagai Google Campus.

${ }^{27}$ Ibid., h. 14.

28Ibid., h. 15-16. 
Google Inc. adalah perusahaan IT yang menyediakan layanan Google Maps dan GE. Perusahaan ini termasuk perusahaan IT raksasa di dunia, seperti halnya Microsoft (pembuat sistem operasi Windows), Yahoo! (Pemilik portal yahoo!), dan Sun Mycrosystem (pembuat sistem operasi Solaris dan bahas pemrograman java). Google Inc. di NASDAQ tercantum dengan nama GOOG, sedangkan di London Stock Exchange/ LSA menggunakan GGEA. Google adalah perusahaan publik yang berbasis di Amerika Serikat. Perusahaan ini resmi dibentuk pada tanggal 17 September 1998.29

\section{Basis Teori Google Earth}

Berdasarkan pada analisis cara kerja software ini, maka dapat disimpulkan bahwa software ini merupakan aplikasi teori keilmuan geomatika yang masih termasuk pada ilmu Geodesi. Menurut Kahar (2008), istilah geomatika (geomatics) dimunculkan tahun 1969 oleh B. Dubuisson. Istilah ini pertama kali digunakan di Canada. Secara umum geomatika adalah kegiatan hunter and gatherer yang dapat diterjemahkan sebagai mengumpulkan dan menggabungkan termasuk alat dan teknik yang digunakan dalam pengukuran tanah (land surveying), penginderaan jauh, GIS, GPS, dan hal lain yang terkait dengan pemetaan permukaan Bumi. ${ }^{30}$

Merujuk pada literatur yang membahas keilmuan Geodesi, maka GE merupakan bentuk teknologi sistem informasi geografis (SIG) yang diolah menjadi software untuk menyajikan data titik koordinat dan untuk keperluan lainnya. Ini sebagaimana banyaknya pemanfaatan teknologi SIG untuk berbagai keperluan seperti pemetaan dengan berbagai tema, penataan ruang, pengelolaan sumber daya alam dan lingkungan, untuk perencanaan pembangunan ekonomi baik makro maupun mikro, penanganan kriminal, analisis pertahanan dan keamanan.

Dalam aplikasinya mencari titik koordinat Bumi, software ini membutuhkan koneksi internet dengan kecepatan tinggi saat dilakukan secara online. Karena ketika menggunakan GE pengguna harus mengunduh terlebih dahulu

\footnotetext{
${ }^{29}$ Ibid., h. 13-15.

30Joenil Kahar, Geodesi, h. 222. 
aplikasi GE secara online. Setelah itu untuk memanfaatkannya dapat dilakukan dengan dua cara yaitu secara online maupun dengan cara offline. Untuk penggunaan secara offline maka pengguna harus mengunduh dahulu wilayah yang akan dijadikan objek kajian sehingga dapat memudahkan.

\section{Aplikasi dalam Penentuan Arah Kiblat}

Aplikasi GE adalah aplikasi free yang dapat dipakai atau diperoleh dengan mudah dari Google Inc tanpa harus mengeluarkan biaya. Supaya bisa melakukan instalasi aplikasi GE di komputer, user terlebih dahulu harus mengambil installer-nya dari internet dan mengaplikasikan program ini untuk mengetahui arah kiblat suatu tempat di permukaan Bumi. GE pada dasarnya digunakan untuk mengetahui informasi suatu posisi atau titik koordinat suatu tempat. Aplikasinya dalam arah kiblat yakni mengetahui suatu tempat dan titik Ka'bah dengan memasukan informasi titik koordinatnya pada My places yang kemudian menggunakan tool ruler yang ada untuk mengetahui azimut kiblat tempat tersebut.

\section{Penentuan Titik Koordinat Bumi dan Arah Kiblat Menggunakan Tongkat Istiwa', Global Positioning System (GPS), dan Google Earth (GE)}

Penentuan arah kiblat menggunakan aplikasi tongkat Istiwa', GPS, dan GE, menghasilkan data perhitungan yang berbeda. Dalam hal ini penulis mengambil titik koordinat suatu tempat yang sama yakni di depan Masjid Baiturrahman Simpang Lima Semarang pada tanggal 30 April 2013. Adapun input data yang diperoleh oleh ketiga alat tersebut yaitu:

\section{Pengamatan Menggunakan Tongkat Istiwa'}

Pada pukul 11: 35 WIB, bayangan terpendek dari tongkat sepanjang 44.9 $\mathrm{cm}$ adalah $18 \mathrm{~cm}$. Dengan memasukan ukuran panjang tongkat dan bayangan ke dalam rumus perhitungan maka diperoleh hasil titik koordinat 070 01' 41.43” LS dan $110^{\circ} 33^{\prime} 30.00^{\prime \prime} .31$

\footnotetext{
${ }^{31}$ Proses perhitungan titik koordinat ini sebagaimana yang telah dijelaskan pada sub bahasan sebelumnya.
}

AL-AHKAM

p-ISSN: 0854-4603; e-ISSN: 2502-3209

Volume 26, Nomor 1, April 2016 


\section{Pengamatan GPS}

Pengukuran GPS dilakukan sebelum dilakukan pengamatan tongkat istiwa'. Pengamatan GPS untuk menentukan titik koordinat ini dimulai pukul 11:23 WIB sampai dengan pukul 11:32 WIB (sekitar 9 menit), dengan kondisi satelit 3-4 satelit. Dimensi berubah-ubah antara 2 dan 3. Ketinggian tempat bervariasi dari 18 meter s.d 72 meter. Data lintang dan bujur bervariasi dalam satuan detik, sehingga diambil data yang paling tetap yaitu 06 59' 20.70" LS dan $110^{\circ} 25^{\prime} 20.00^{\prime \prime}$ BT.

\section{Pengamatan Google Earth}

Pengamatan menggunakan GE ini dilakukan pada tanggal 30 April 2013 dengan mengambil lokasi yang sama yaitu teras depan Masjid Baiturrahman Simpang Lima Semarang. Dengan menggunakan aplikasi sotware ini, maka diperoleh hasil pencitraan satelit sebagaimana berikut ini:

Hasil print screen kondisi Masjid Baiturrahman dengan beberapa keterangan yakni hasil pemotretan pada (imagery date) 6/27/2010 dengan tinggi lihat (eye alt) 1227 kaki diperoleh titik koordinat yaitu 06 59' 20.75" LS dan $110^{\circ}$ 25' 20.05". Pemilihan lokasi pengamatan ini mengambil lokasi yang dimungkinkan dalam beberapa tahun tidak terjadi perubahan. Sehingga pengambilan titik merupakan prediksi yaitu sekitar $06^{\circ} 59^{\prime} 20.75^{\prime \prime}$ LS dan $110^{\circ} 25^{\prime}$ 20.05" BT.

Setelah diketahui titik koordinat dengan masing-masing alat, maka dibuat tabel yang menyajikan perbedaan selisih data lintang dan bujur yang dihasilkan setiap alat yaitu sebagaimana tabel berikut ini:

Tabel 1.

Data Lintang dan Bujur Menggunakan Tongkat Istiwa', GPS, dan Google Earth

\begin{tabular}{|c|c|c|c|}
\hline Data & Tongkat istiwa' & GPS & Google Earth \\
\hline Lintang & $07^{\circ} 01^{\prime} 41.45^{\prime \prime}$ & $06^{\circ} 59^{\prime} 20.70^{\prime \prime}$ & $06^{\circ} 59^{\prime} 20.75^{\prime \prime}$ \\
\hline Bujur & $110^{\circ} 33^{\prime} 30.00$ & $110^{\circ} 25^{\prime} 20.00^{\prime \prime}$ & $110^{\circ} 25^{\prime} 20.05^{\prime \prime}$ \\
\hline
\end{tabular}

Untuk mengetahui jarak panjang busur selisih kedua lintang, maka dapat diperoleh dengan menggunakan rumus berikut ini: 
Tongkat Istiwa', Global Positioning System (GPS) dan Google Earth ...

$$
\begin{array}{ll}
s=\frac{l}{2 \pi R} \times 360^{\circ} & \text { Keterangan: } \\
l=\frac{\mathrm{l}=\text { jarak }}{360^{\circ}} & \mathrm{s}=\text { sudut } \\
l \mathrm{R}=\text { jari-jari tempat pengamatan }
\end{array}
$$

Karena posisi pengamatan dilakukan pada kisaran lintang 6 derajat, maka jari-jari lintang tempat tersebut diperhitungkan juga yaitu menggunakan rumus:

$$
\begin{array}{ll}
r \text { (jari-jari lingkaran kecil Bumi) } & =R \cdot \cos \varphi \\
r & =6.356 .752,314 \cdot \cos 6^{\circ} \\
r & =6.321 .929,36 \mathrm{~m}
\end{array}
$$

Kemudian dimasukan ke dalam rumus:

$$
\begin{aligned}
& \mathrm{l}=00^{\circ} 02^{\prime} 20.75^{\prime \prime} \times 2 \pi(6.321 .929,36) / 360^{\circ} \\
& \mathrm{l}=4.313,927921 \text { meter }(4,3 \mathrm{~km})
\end{aligned}
$$

Perbedaannya yakni sebagaimana tabel berikut ini:

Tabel 2.

\section{Selisih Data Lintang Tongkat Istiwa' dan GPS}

\begin{tabular}{|c|c|c|c|c|}
\hline Data & Tongkat istiwa' & GPS & Selisih & Jarak \\
\hline Lintang & $07^{\circ} 01^{\prime} 41.45^{\prime \prime}$ & $06^{\circ} 59^{\prime} 20.70^{\prime \prime}$ & $00^{\circ} 02^{\prime} 20.75^{\prime \prime}$ & $4,3 \mathrm{~km}$ \\
\hline
\end{tabular}

Sedangkan jika melihat data lintang yang dihasilkan GPS dan GE menunjukkan selisih yang tidak terlalu signifikan sehingga dianggap sama yakni kisaran selisih 1,532 m sebagaimana berikut ini:

Tabel 3.

\section{Selisih Data Lintang GPS dan Google Earth}

\begin{tabular}{|c|c|c|c|c|}
\hline Data & GPS & Google Earth & Selisih & Jarak \\
\hline Lintang & $06^{\circ} 59^{\prime} 20.70^{\prime \prime}$ & $06^{\circ} 59^{\prime} 20.75^{\prime \prime}$ & $00^{\circ} 00^{\prime} 00.05^{\prime \prime}$ & $1,532 \mathrm{~m}$ \\
\hline
\end{tabular}

Kemudian perbedaan bujur hasil pengamatan tongkat istiwa' dan GPS yaitu sebagaimana tabel berikut ini: 
Tabel 4.

Selisih Data Bujur GPS dan Google Earth

\begin{tabular}{|c|c|c|c|c|}
\hline Data & Tongkat istiwa $^{\prime}$ & GPS & Selisih & Jarak \\
\hline Bujur & $110^{\circ} 33^{\prime} 30.00^{\prime \prime}$ & $110^{\circ} 25^{\prime} 20.00^{\prime \prime}$ & $00^{\circ} 08^{\prime} 10^{\prime \prime}$ & $15,01 \mathrm{~km}$ \\
\hline
\end{tabular}

Kemudian analisis selanjutnya yakni mengetahui selisih arah kiblat dengan menggunakan data lintang dan bujur yang telah dihasilkan ketiga alat tersebut. ${ }^{32}$ Namun dalam hal ini yang penting diketahui adalah tongkat istiwa' dengan GPS berdasarkan pada persamaan hasil perhitungan kiblat antara GPS dan GE sebelumnya:

Tabel 5.

\section{Perbandingan Sudut Arah Kiblat dengan Input Data (dari Tongkat Istiwa', GPS, dan Google Earth)}

\begin{tabular}{|c|c|c|c|}
\hline Data & Tongkat istiwa' & GPS & Google Earth \\
\hline Sudut kiblat & $294^{\circ} 28^{\prime} 43.00^{\prime \prime}$ & $294^{\circ} 30^{\prime} 03.00^{\prime \prime}$ & $294^{\circ} 30^{\prime} 03.00^{\prime \prime}$ \\
\hline
\end{tabular}

Dari perhitungan di atas, diketahui sudut kiblat memiliki hasil yang sama yakni menggunakan GPS dan GE. Sedangkan selisih perbedaan sudut kiblat dengan menggunakan input data tongkat istiwa' dengan dua alat lainnya yakni sekitar 00॰ 01' 19.21" (satuan menit). Jika satuan menit ini diubah menjadi satuan jarak, maka penyimpangan kiblatnya yaitu: ${ }^{33}$

1. Menghitung jarak antara Lokasi dengan Ka'bah

$$
\begin{aligned}
& \mathrm{E}=\mathrm{BT}-\mathrm{BM} \\
& \mathrm{M}=\cos ^{-1}(\sin \mathrm{LT} \times \sin \mathrm{LK}+\cos \mathrm{LT} \times \cos \mathrm{LK} \times \cos \mathrm{E}) \\
& \mathrm{Km}=\mathrm{M} / 360 \times 6,283185307 \times 6.356 .752 \\
& \text { Keterangan: } \\
& \mathrm{E} \quad=\text { selisih bujur tempat dan bujur Ka'bah }
\end{aligned}
$$

\footnotetext{
32Perhitungan arah kiblat yang penulis pakai, menggunakan data lintang dan bujur Ka'bah 21 $25^{\prime}$ 21.17" LU dan 39o 49' 34.56" BT.

33Rumus perhitungan ini diperoleh dari tulisan Ibnu Zahid Abdo el-Moeid, Menghitung Arah Kiblat dan Menentukannya di http://moeidzahid.site90.net
} 
$\mathrm{BT}=$ bujur tempat

$\mathrm{BM}=$ bujur Mekah

$\mathrm{M}$ = perhitungan sudut

$\mathrm{Km}$ = perhitungan dalam bentuk jarak $(\mathrm{km})$

$6,283185307=2 \pi$

$6.356 .752=$ jari-jari Bumi

2. Menghitung penyimpangan dari Ka'bah

$\mathrm{P}=\mathrm{Km} / \sin ((180-\mathrm{S}) / 2) \mathrm{x} \sin \mathrm{S}$

Keterangan:

$\mathrm{P} \quad$ = penyimpangan dari ka'bah dalam kilometer

$\mathrm{Km}=$ jarak antara ka'bah dengan lokasi dalam kilometer

$\mathrm{S}$ = sudut kesalahan dalam derajat

Dari rumus perhitungan di atas, diketahui sudut penyimpangan:

$\mathrm{E}=\mathrm{BT}-\mathrm{BM}$

$\mathrm{E}=110^{\circ} 33^{\prime} 30.00^{\prime \prime}-39^{\circ} 49^{\prime} 34.56^{\prime \prime}$

$\mathrm{E}=70^{\circ} 43^{\prime} 55.44^{\prime \prime}$

$\mathrm{M}=\cos ^{-1}(\sin \mathrm{LT} \mathrm{x} \sin \mathrm{LK}+\cos \mathrm{LT} \mathrm{x} \cos \mathrm{LK} \mathrm{x} \cos \mathrm{E})$

$\mathrm{M}=\cos ^{-1}\left(\sin -07^{\circ} 01^{\prime} 41.45^{\prime \prime} \mathrm{x} \sin 21^{\circ} 25^{\prime} 21.17^{\prime \prime}+\cos -07^{\circ} 01^{\prime} 41.45^{\prime \prime} \mathrm{x}\right.$ $\left.\cos 21^{\circ} 25^{\prime} 21.17^{\prime \prime} \times \cos 70^{\circ} 43^{\prime} 55.44^{\prime \prime}\right)$

$\mathrm{M}=74^{\circ} 30^{\prime} 06.64^{\prime \prime}$

$\mathrm{Km}=\mathrm{M} / 360 \times 6,283185307 \times 6.356 .752$

$\mathrm{Km}=74 \mathrm{o} 30^{\prime} 06.64 / 360 \times 6,283185307 \times 6.356,752$

$\mathrm{Km}=8.311,947111 \mathrm{~km}$

$\mathrm{P}=\mathrm{Km} / \sin ((180-\mathrm{S}) / 2) \mathrm{x} \sin \mathrm{S}$

$\mathrm{P}=8.311,947111 / \sin \left(\left(180 \mathrm{o}-00 \mathrm{o} 01^{\prime} 20.00^{\prime \prime}\right) / 2\right) \mathrm{x} \sin 00 \mathrm{o} 01^{\prime} 20.00^{\prime \prime}$

$\mathrm{P}=3,22 \mathrm{~km}$ 
Tabel 6.

Selisih Sudut Kiblat (Input Data Tongkat Istiwa'dan GPS) dalam Satuan Jarak

\begin{tabular}{|c|c|c|c|c|}
\hline Data & Tongkat istiwa' & GPS & Selisih & Jarak \\
\hline Kiblat & $294^{\circ} 28^{\prime} 43.00^{\prime \prime}$ & $294^{\circ} 30^{\prime} 03.00^{\prime \prime}$ & $00^{\circ} 01^{\prime} 20.00^{\prime \prime}$ & $3,22 \mathrm{~km}$ \\
\hline
\end{tabular}

Berdasarkan pada hasil pengamatan di atas, tongkat istiwa' memiliki perbedaan selisih satuan menit dengan GPS dan GE. Hal ini disebabkan selain dari cara pengukurannya, tongkat istiwa' menggunakan pengamatan ketinggian Matahari. Hasil dari beberapa kali pengamatan baik pada tempat dan waktu yang berbeda maka diperoleh selisih perbedaan yang mencakup satuan menit. Kemudian, hasil pengamatan lainnya menunjukkan persamaan hasil data yaitu GPS dan GE (satuan detik).

Tongkat istiwa' memiliki kelebihan di antaranya segi kepraktisan karena dilakukan tanpa penggunaan teknologi tinggi. Hal ini karena pengukuran cukup sederhana, hanya menggunakan sinar Matahari, tongkat, dan tempat yang datar. Tidak diperlukan peralatan canggih dan dapat dilakukan di tempat manapun selama ada Matahari yang sinarnya sampai ke tongkat sehingga cara ini dapat dilakukan oleh masyarakat Muslim di manapun dengan tanpa kekhawatiran kurang akurat.

Pada tataran aplikasi alat ini memang cukup menguras tenaga karena pengamat harus terus memantau bayangan tongkat paling pendek ketika hari itu dan memerlukan pengukuran ekstra hati-hati. Namun data hasil pengukuran cukup mendekati hasil GPS dan GE. Hasil perhitungan lintang menggunakan tongkat istiwa' dengan GPS dan GE memiliki selisih perbedaan yang terletak pada satuan menit.

Selain itu, hasil pengukuran lintang dan bujur menggunakan tongkat istiwa' perlu diperhatikan data deklinasi Mataharinya (geosentris) karena sangat mempengaruhi hasil. Akan lebih baik jika hasil dari perhitungan tongkat istiwa' dilakukan reduksi menjadi lintang geodetik (geografis). ${ }^{34}$

${ }^{34}$ jika hasil pengukuran lintang menggunakan tongkat istiwa' menggunakan data deklinasi Matahari (geosentrik) yang ada pada tabel-tabel seperti ephemeris, maka untuk menjadikan lebih

86 Volume 26, Nomor 1, April 2016

AL-AHKAM p-ISSN: 0854-4603; e-ISSN: 2502-3209 
Pengukuran metode ini diperlukan adanya keakuratan dalam reduksi lintang dan dalam penyajian informasi waktu, sehingga pengukuran tidak terjadi kesalahan karena semakin manual metode, maka semakin banyak human error yang akan sangat mungkin terjadi.

GPS tipe navigasi yang sering kali digunakan untuk menentukan lintang dan bujur pada umumnya memiliki kepraktisan karena termasuk produk teknologi yang dapat dibawa, namun yang perlu diperhatikan dari penggunaan GPS tipe navigasi ini adalah pada saat pengambilan data yang keliru karena metode ini bergantung pada sistem kontrol dan sistem satelit yang tersedia sehingga diperlukan adanya posisi yang bagus untuk mendapatkan sinyal satelit. Pengambilan data yang baik tetap memerlukan posisi ideal yakni di tempat yang terbuka tanpa terhalang bangunan, pohon, atau pun tiang-tiang listrik. Hal ini dikarenakan dikhawatirkan pula adanya bias pada atmosfer yang dapat mempengaruhi sinyal satelit dalam menyampaikan informasi data. Kalaupun diinginkan hasil pengukuran dengan ketelitian tinggi, pengguna bisa menggunakan GPS tipe survei, namun sayangnya peralatan yang dipakai baik software dan hardware-nya sangat mahal dan tidak lazim dipakai (tidak mudah dioperasikan) orang kebanyakan.

GE cukup dapat memberikan gambaran luas tentang posisi tempat yang diinginkan, namun tidak pada setiap tampilan tempat-tempat di permukaan Bumi diperoleh gambar yang jelas dan bersih sebagaimana gambar dari yang ditampilkan kondisi di depan Masjid Baiturrahman Simpang Lima Semarang Jawa Tengah. Hal ini akan ditemui ketika pengguna ingin mendapatkan titik koordinat benar dan tepat pada suatu tempat di daerah perumahan atau pun perkampungan. Tampilan yang muncul terkadang buram sehingga membingungkan pengguna untuk dapat memperoleh informasi titik koordinat yang tepat.

Tongkat istiwa' sebagai alat untuk mengukur lintang dan bujur tempat telah dapat dibuktikan. Alat ini termasuk dalam kategori alat pengukuran yang

akurat bisa dilakukan koreksi dengan mengubah lintang geosentrik hasil pengukuran menjadi geodetik. Untuk contoh yang sudah ada yakni pada 30 April 2013 yaitu $07^{\circ} 01^{\prime} 41.45^{\prime \prime}$, maka lintang geodetiknya adalah 06 58' 53.75” (mendekati lintang GPSyaitu 06 59' 20.75”). 
mendekati akurat, meski memiliki selisih menit dari penggunaan alat yang sudah modern. Tongkat istiwa' cukup dapat mewakili penggunaan alat-alat tradisional ilmu falak yang menghasilkan perhitungan yang mendekati keakuratan. Untuk mengetahui akurasi tongkat istiwa' ini penulis melakukan perhitungan azimut kiblat sebagaimana pada penjelasan sebelumnya yang menunjukkan adanya deviasi $3 \mathrm{~km}$ (untuk Masjid Baiturrahman Simpang Lima Semarang) sehingga penyimpangan arah kiblat dengan input data tongkat istiwa' tidak sampai menyebabkan garis kiblat menyimpang dari area kota Mekah. ${ }^{35}$

\section{Kesimpulan}

Berdasarkan uraian analisis di atas dapat ditarik kesimpulan penelitian sebagaimana berikut:

Pertama, metode penentuan titik koordinat Bumi menggunakan tongkat istiwa' adalah metode penentuan lintang dan bujur Bumi menggunakan kaidah trigonometri bola. Perhitungannya menggunakan referensi lingkaran besar (great circle) yakni memanfaatkan posisi Matahari pada saat kulminasi untuk diketahui sudut posisi Matahari terhadap nilai lintang Bumi pada bola langit. Sedangkan penentuan lintang dan bujur menggunakan GPS handheld adalah metode penentuan dengan memanfaatkan sinyal satelit, di mana kerangka bentuk Bumi yang digunakan adalah ellipsoida. Penentuan lintang dan bujur menggunakan GE adalah penentuan lintang dan bujur melalui software yang sumber datanya berasal dari kumpulan foto citra satelit.

Kedua, dari ke tiga metode penentuan lintang dan bujur suatu tempat di permukaan Bumi yaitu tongkat istiwa', GPS, dan GE, maka dapat disimpulkan berdasarkan pandangan teori dan aplikasinya. Berdasarkan teori dapat dibagi menjadi dua yaitu metode yang berpijak pada teori astronomi dan teori

\footnotetext{
35Berdasarkan perhitungan (Khafid, 2010:19), apabila pinggiran paling Utara atau paling Selatan kota Mekah berjarak 6 km dari Ka'bah, maka untuk mengarahkan masjid-masjid di Indonesia ke arah Mekah dibutuhkan ketelitian maksimal 3 menit busur. Oleh karena itu, penggunaan tongkat istiwa' dalam menyajikan data titik koordinat cukup mendekati hasil arah kiblat yang tidak keluar dari kota Makkah.
} 
geodesi. Pengaruh teori ini dapat terlihat pada sistem perhitungannya. Teori astronomi sebagaimana terlihat pada penggunaan tongkat istiwa', perhitungannya menggunakan kerangka segitiga bola dan menggunakan input data posisi Matahari secara geosentrik. Sedangkan teori Geodesi terlihat pada sistem yang digunakan oleh GPS dan software GE. Keduanya merupakan produk teori Geodesi di mana bentuk pendekatan yang dipakai bukan bola, melainkan ellipsoida. Sedangkan pada tataran aplikasi diperoleh kesimpulan bahwa metode paling praktis dan akurat dari ketiga alat itu secara berurutan adalah GPS, GE, dan tongkat istiwa'.[a]

\section{DAFTAR PUSTAKA}

Abidin, Hasanuddin, Geodesi Satelit, Jakarta: PT. Pradnya Paramita, 2001.

Azhari, Susiknan, Ensiklopedi Hisab Rukyah, Cet I, Yogyakarta: Pustaka Pelajar, 2005.

Azhari, Susiknan, Ilmu Falak Perjumpaan Khazanah Islam dan Sains Modern, Cet. 2, Yogyakarta: Suara Muhammadiyah, 2007.

Basrowi, dan Suwandi, Memahami Penelitian Kualitatif, Jakarta: Rineka Cipta, 2008.

Depag RI, Pedoman Penentuan Arah Kiblat, Direktorat Jenderal Pembinaan Kelembagaan Agama Islam, Direktorat Pembinaan Badan Peradilan Agama Islam, 1995.

Djambek, Saadoeddin, Arah Qiblat dan Cara Menghitungnya dengan Jalan Ilmu Ukur Segi Tiga Bola, Jakarta: Tintamas, 1957.

Ekadinata, Andree, dkk., Sistem Informasi Geografis untuk Pengelolaan Bentang Lahan Berbasis Sumber Daya Alam, Bogor, World Agoforestry Centre, 2008.

Efistek.com, Menjelajah Dunia dengan Google Earth dan Maps, Bandung: CV. Yrama widya, 2006.

Ghani, Muhammad Ilyas Abdul, Sejarah Mekah Dulu dan Kini, Cet. ke 3, Madinah Munawwarah: Al-Rasheed Printers, 2004.

Hadi, Dimsiki, Sains untuk Kesempurnaan Ibadah (Penerapan Sains dalam Peribadatan), Yogyakarta: Primapustaka, 2009.

Halim, Abdul, Ensiklopedia Haji dan Umrah, Jakarta: Raja Grafindo Persada, 2002. 
Hambali, Slamet, Ilmu Falak I (Penentuan Awal Waktu Shalat dan Penentuan Arah Kiblat Seluruh Dunia), Semarang: Pascasarjana IAIN Walisongo, 2011.

, Pengantar Ilmu Falak, Menyimak Proses Pembentukan Alam Semesta, Semarang, Banyuwangi: Bismillah Publiser, 2012.

Ilyas, Mohammad, a Modern Guide to Astronomical Calculations of Islamic Calendar, Times, and Qibla, Kuala Lumpur: Berita Publishing Sdn.Bhd, 1984.

Al-Jazīrī, 'Abd al-Rahmān, Kitāb al-fiqh 'alā al-madhahib al-arba'ah, Juz 1, Beirut: Dār al-Kutub al-'alamiyah, t.th.

Kahar, Joenil, Geodesi, Bandung: ITB, 2008.

Khazin, Muhyiddin, Ilmu Falak dalam Teori dan Praktik, Cet I, Jogyakarta: Buana Pustaka, 2004.

King, David A., Islamic Mathematical Astronomy, London: Variorum Reprints, 1986.

World-Maps for Finding the Direction and Distance to Mecca Inovation and Tradition in Islamic Science, Brill: the Neterlands, 1999.

Krakiwsky, W. J. dan D. E. Wells, Coordinate Systems in Geodesy, Canada: Departement of Geodesy and Geomatics Engineering University of New Brunswick Frederiction, N.B, 1971.

Mughniyah, Muhammad Jawad, Fiqh Lima Madzhab, Jakarta: Basrie Press, 1991.

Munawir, Warson, al-Munawir Kamus Arab-Indonesia, Surabaya: Pustaka Progressif, 1997.

Nazir, Muhammad, Metode Penelitian, Jakarta: Ghalia Indonesia, 1988.

Perpustakaan Nasional: Katalog dalam Terbitan (KDT), THAB Teknik Hidup di Alam Terbuka, Bandung: Truenorth, 2011.

Purwanto, Agus, Pengantar Kosmologi, Surabaya: ITS Press, 2009.

Radiman, Iratus, dkk, Ensiklopedi Singkat Astronomi dan Ilmu yang Bertautan, Bandung: ITB, 1980.

Rahim, Abdul, Ilmu Falak, Yogyakarta: Liberty, 1983.

Rais, Heppy El, Kamus Ilmiah Populer, Yogyakarta:Pustaka Pelajar, 2012.

Ruggles, Clive, Ancient Astronomy, An Encyclopedia of Cosmologies and Myth, California, ABC-CLIO, 2005. 
Satori, Djam'an, dan Aan Komariyah, Metodologi Penelitian Kualitatif, Bandung: Alfabeta, 2009.

Simamora, P., Ilmu Falak (Kosmografi), Jakarta: Pedjuang Bangsa, 1985.

Smart, W.M, Textbook on Spherical Astronomy, New York: Cambridge University Press, 1977.

Subana, M, Dasar-dasar Penelitian Ilmiah, Bandung: Pustaka Setia, 2005.

Sugiyono, Metode Penelitian Kuantitatif Kualitatif dan R\&D, Bandung: Alfabeta, 2008.

Suwitra, Nyoman, Astronomi Dasar, Singaraja: Institut Keguruan dan Ilmu Pendidikan Negeri, t.th.

Vilanueva, K.J., Pengantar ke dalam Astronomi Geodesi, Bandung: Departemen Geodesi Fak. Teknik Sipil dan Perencanaan Institut Teknologi Bandung, 1978.

\section{Skripisi/ Thesis/ Disertasi}

Abidin, Hasanuddin, "Implikasi Galat Penentuan Arah Kiblat dan Deviasinya", Bandung: ITB, 2008.

\section{Makalah}

Badan Standarisasi Nasional, Jaring Kontrol Horizontal, SNI 19-6724-2002

Darsa Sukaetadireja, "Teknik Observasi Posisi Matahari untuk Menentukan Waktu Shalat dan Arah Kiblat". Makalah yang disampaikan dalam Workshop Nasional mengkaji Ulang Metode Penetapan Awal Waktu Shalat dan Arah Kiblat dalam perspektif Ilmu Syariah dan Astronomi di UII Yogyakarta, 2009.

\section{Website}

http://moeidzahid.site90.net

http://garmin.co.id.

Winhisab 2010 v.2.1 Kementerian Agama RI 
92 || Volume 26, Nomor 1, April 2016 